\title{
A clinical study of fetomaternal outcome in pregnancy with polyhydramnios
}

\author{
Aditi Anil Rajgire*, Kiran Rajendra Borkar, Amruta Madan Gadge
}

Department of Obstetrics and Gynecology, Datta Meghe Institute of Medical Sciences University, Sawangi (Meghe), Wardha, Maharashtra, India

Received: 20 October 2016

Accepted: 15 November 2016

\section{*Correspondence:}

Dr. Aditi Anil Rajgire,

E-mail: adt_rajgire@yahoo.com

Copyright: (C) the author(s), publisher and licensee Medip Academy. This is an open-access article distributed under the terms of the Creative Commons Attribution Non-Commercial License, which permits unrestricted non-commercial use, distribution, and reproduction in any medium, provided the original work is properly cited.

\begin{abstract}
Background: Amniotic fluid not only provides protection to the fetus from traumatic forces, cord compression, and microbial pathogens, but also plays an integral role in the normal development of the fetal musculoskeletal, pulmonary, and gastrointestinal systems. Polyhydramnios, defined as an excessive amount of amniotic fluid, complicates approximately $0.4-3.3 \%$ of all pregnancies. Fetal conditions that are associated with polyhydramnios include major congenital anomalies and both the immunologic and non-immunologic forms of hydrops foetalis. Maternal medical conditions are also known to be associated with polyhydramnios and subsequently alter perinatal outcome. So by diagnosing these cases as early as possible, these maternal complications can be prevented and advise proper prenatal counseling in relevant cases.

Methods: This study was conducted in obstetrics and gynaecology department at a tertiary care hospital, over the period of from September 2015 to September 2016. Prospective observational study.

Results: Polyhydramnios is commoner in primigravida. Causative factor are mainly idiopathic after which the most important is fetal defects. Diabetes is also associated finding with polyhydramnios in $8.3 \%$ cases. The occurrence of fetal congenital abnormality was directly proportional to the gestational age of pregnancy. Incidence of congenital abnormality was found to be $1.25 \%$. Congenital heart disease and cleft lip and cleft palate (3\%) were the commonest congenital abnormality associated with polyhydramnios followed by anencephaly and spina bifida (3.3\%).

Conclusions: In our study Idiopathic polyhydramnios was found to be the most common cause of polyhydramnios. A careful study must be done for detection of etiological factors in all cases of polyhydramnios, careful screening, prenatal and antenatal counseling will help to improve the foetal outcome as well as to prevent the maternal complication.
\end{abstract}

Keywords: Congenital anomalies, Polyhydramnios

\section{INTRODUCTION}

The amniotic fluid is of both maternal and foetal origin. ${ }^{1}$ Its volume is controlled by dynamic interactions among the foetal, placental and maternal compartments. ${ }^{2}$ Throughout normal pregnancy, the amniotic fluid allows the foetus a room for growth, movement and development. It protects the foetus from sudden jerks and serves as a cushion. In polyhydramnios this equilibrium shifts so that the net transfer of water is into the amniotic sac. ${ }^{3}$ This polyhydramnios is often indicative of foetal, placental or maternal problem. It occurs in about $1 \%$ of pregnancy. ${ }^{4}$ Polyhydramnios is defined as deepest vertical pool (DP) more or equal than $8 \mathrm{~cm}$ or amniotic fluid index (AFI) of equal or more than $24 \mathrm{~cm}$ or AFI above the 95 th percentile for gestational age. ${ }^{5,6}$ 
AFI is determined by directly measuring the vertical pocket (free of any foetal part) in four quadrants of abdomen in a pregnant woman polyhydramnios is ranked as mild, moderate or severe according to AFI 24.0-29.9 $\mathrm{cm}, 30.0-34.9 \mathrm{~cm}$ and $35.0 \mathrm{~cm}$ or more respectively. ${ }^{7,8}$ There is dominant role of anomalous foetal development in the production of polyhydramnios but discrepancy still exists regarding the reported frequency of anomalies among foetuses in pregnancies complicated with polyhydramnios. ${ }^{9}$ This disparity is due to cut off level for establishing polyhydramnios. It is observed that with increasing severity of polyhydramnios, percentage of anomalous foetusincreases. ${ }^{10}$

Perinatal morbidity and mortality are significantly increased when polyhydramnios is present at delivery. Fetal conditions that are associated with polyhydramnios include major congenital anomalies (open neural tube defects, upper gastrointestinal tract obstruction or malformation etc.) and both the immunologic and nonimmunologic forms of hydrops foetalis. Maternal medical conditions are also known to be associated with polyhydramnios and subsequent altered perinatal outcome (eg. diabetes mellitus, pre-eclampsia, malpresentation, premature rupture of membrane, preterm labour and accidental haemorrhage are the very well-known complications of polyhydramnios during preganancy and cord prolapse, uterine inertia, retained placenta and postpartum haemorrhage are the expected complications of polyhydramnios during labour. So by diagnosing these cases as early as possible, we can prevent these maternal complications and do the proper prenatal counselling in the relevant cases.

\section{METHODS}

This study was conducted in obstetrics and gynaecology department at a tertiary care hospital, over the period of from September 2015 to September 2016. After a thorough physical examination and detailed history of the patients, clinical diagnosis of polyhydramnios was confirmed by ultrasound after which they were included in the study and proforma was filled.

Routine lab investigation was done. Complete labor record was made along with mode of delivery and duration. Complete physical examination of baby by obstetrician and pediatrician with recording of Apgar score and any anomalies found. Data thus collected was analyzed for results and compared with international as well as local studies.

\section{RESULTS}

Majority of cases $90 \%$ were in the gestational age group from 37 weeks to 42 weeks were as only $3.3 \%$ cases were in gestational age group of 20 to 27 weeks and were of acute origin.
Table 1: Distribution according to the gravida amongst patients with polyhydramnios and normal liquor.

\begin{tabular}{|lll|}
\hline Gravida & Polyhydramnios & Percentage \\
\hline Primigravida & 24 & $40 \%$ \\
\hline Gravida 2 & 20 & $33.3 \%$ \\
\hline Gravida $>2$ & 16 & $26.6 \%$ \\
\hline Total & $\mathbf{6 0}$ & $\mathbf{1 0 0 \%}$ \\
\hline
\end{tabular}

Maximum cases were primigravida.

Table 2: Gestational age associated with polyhydramnios.

\begin{tabular}{|lll|}
\hline $\begin{array}{l}\text { Gestational- } \\
\text { age (in weeks) }\end{array}$ & $\begin{array}{l}\text { No. of cases of } \\
\text { polyhydramnios }\end{array}$ & Percentage \\
\hline $20-27$ weeks & 02 & $3.3 \%$ \\
\hline $28-36$ weeks & 04 & $6.6 \%$ \\
\hline $37-42$ weeks & 54 & $90 \%$ \\
\hline Total & $\mathbf{6 0}$ & $\mathbf{1 0 0 \%}$ \\
\hline
\end{tabular}

Majority of cases $90 \%$ were in the gestational age group from 37 weeks to 42 weeks were as only $3.3 \%$ cases were in gestational age group of 20 to 27 weeks and were of acute origin.

Table 3: Increasing gestational age association with foetal congenital anamoly in cases of polyhydramnios.

\begin{tabular}{|ll|l|}
\hline $\begin{array}{l}\text { Gestational } \\
\text { age (in weeks) }\end{array}$ & $\begin{array}{l}\text { Polyhydramnios } \\
\text { associated with } \\
\text { foetal congenital } \\
\text { anmoly }\end{array}$ & $\begin{array}{l}\text { Polyhydramnios } \\
\text { not associated wit } \\
\text { foetal congenital } \\
\text { anamoly }\end{array}$ \\
\hline 20 - 27 weeks & 0 & 02 \\
\hline 28 - 36 weeks & 02 & 04 \\
\hline $37-40$ week & 15 & 37 \\
\hline Total & $\mathbf{1 7}$ & $\mathbf{4 3}$ \\
\hline
\end{tabular}

2-value $=38.72, \mathrm{p}$-value $=0.0001$, Significant.

Table 4: Maternal conditions associated with polyhydraminos.

\begin{tabular}{|lll|}
\hline $\begin{array}{l}\text { Maternal } \\
\text { condition }\end{array}$ & $\begin{array}{l}\text { Polyhydraminos } \\
\text { patients }\end{array}$ & Percentage \\
\hline Preclampsia & 10 & $16.6 \%$ \\
\hline Hypothyroidism & 03 & $5 \%$ \\
\hline $\begin{array}{l}\text { Rh negative blood } \\
\text { group }\end{array}$ & 04 & $6.6 \%$ \\
\hline $\begin{array}{l}\text { Gestational } \\
\text { diabetes mellitus }\end{array}$ & 05 & $8.3 \%$ \\
\hline Anaemia & 10 & $16.6 \%$ \\
\hline Sickle cell trait & 03 & $5 \%$ \\
\hline $\begin{array}{l}\text { No associated } \\
\text { condition }\end{array}$ & 25 & $41.6 \%$ \\
\hline
\end{tabular}

As the cases with polyhydramnios reached term there was an increasing association of congenital anamoly. 37 cases had associated foetal congenital anamoly with polyhydramnios which were of gestational age group 37 
to 40 weeks were as only 4 cases of polyhydramnious had associated congenital anamoly between the geastational age group of 28 to 36 weeks. About $58.1 \%$ cases of polyhydramnios had associated maternal condition of which maximum cases had preclampsia and anaemia followed by gestational diabeytes mellitus followed by rhissoimmunization.

Table 5: Maternal complications during delivery.

\begin{tabular}{|lll|}
\hline $\begin{array}{l}\text { Maternal } \\
\text { complications }\end{array}$ & Polyhyraminos & Percentage \\
\hline Preterm labour & 03 & $5 \%$ \\
\hline $\begin{array}{l}\text { Premature rupture of } \\
\text { membranes }\end{array}$ & 03 & $5 \%$ \\
\hline Cord prolapse & 01 & $1.6 \%$ \\
\hline Malpresentation & 04 & $6.6 \%$ \\
\hline Placenta praveia & 02 & $3.3 \%$ \\
\hline Placental abruption & 01 & $1.6 \%$ \\
\hline Eclampsia & 03 & $5 \%$ \\
\hline $\begin{array}{l}\text { Post-partum } \\
\text { haemorrhage }\end{array}$ & 02 & $3.3 \%$ \\
\hline $\begin{array}{l}\text { No maternal } \\
\text { complication during } \\
\text { delivery }\end{array}$ & 41 & $68.3 \%$ \\
\hline
\end{tabular}

Table 6: Fetal outcome in cases of polyhydramnios.

\begin{tabular}{|lll|}
\hline Fetal outcome & Polyhydraminos & Percentage \\
\hline Alive & 54 & $90 \%$ \\
\hline Perinatal death & 03 & $5 \%$ \\
\hline IUD & 03 & $5 \%$ \\
\hline
\end{tabular}

Table 7: Types of congenital anamolies seen polyhydramnios.

\begin{tabular}{|lll|}
\hline $\begin{array}{l}\text { Foetal congenital } \\
\text { anomalies }\end{array}$ & Polyhydraminos & Percentage \\
\hline $\begin{array}{lll}\text { Anencephaly } \\
\text { Cleft Lip + cleft } \\
\text { palate }\end{array}$ & 02 & $3.3 \%$ \\
\hline Spina bifida & 02 & $5 \%$ \\
\hline $\begin{array}{l}\text { Congenital heart } \\
\text { disease }\end{array}$ & 03 & $3.3 \%$ \\
\hline Dudoneal atresia & 02 & $5 \%$ \\
\hline $\begin{array}{l}\text { Oesophageal } \\
\text { atresia }\end{array}$ & 02 & $3.3 \%$ \\
\hline Hydrocephalus & 01 & $3.3 \%$ \\
\hline Absent phalanges & 02 & $1.6 \%$ \\
\hline $\begin{array}{l}\text { No foetal } \\
\text { congenital } \\
\text { anamoly }\end{array}$ & 44 & $3.3 \%$ \\
\hline
\end{tabular}

About $31.4 \%$ of cases of polyhydramnios developed complication during delivery out of which the commonest was malpresentation followed by preterm labour, premature rupture of membranes and eclampsia $5 \%, 3.3 \%$ developed placenta praveia, and $3.3 \%$ developed postpartum haemorrhage. Least common were cord prolapse and placental abruption $1.6 \%$. $90 \%$ of the babies of polyhydramnious were alive were as the percentage of IUD and perinatal death was equal accounting to $5 \%$ each.

$27 \%$ cases of polyhydramnios cases delivered babies with congenital anamoly, commonest congenital anamoly noted was congenital heart defect and cleft lip and cleft palate $5 \%$ cases each, followed by anencephaly, spina bifida, duodenal atresia, oesophageal atresia 3.3\% each. Least common being hydrocephalus.

\section{DISCUSSION}

Polyhydramnios is an uncommon complication associated with pregnancy. Such pregnancies are high risk pregnancies and need to be thoroughly investigated. The clinical problems associated with polyhydramnios, apart from fetal anomaly, are maternal discomfort, difficult clinical examination of fetus and premature labor; it is diagnosed accurately by clinical examination confirmed by ultrasonography. In our study the incidence of polyhydramnios is $1.5 \%$ which is comparable to study by Dr. Saadia Tariq, Dr. Sadia Cheema on Polyhydramnios Study of cases and fetal outcome conducted in Lahore who found the incidence of polyhydramnios as $2.19 \% .^{13}$ In present study the perinatal outcome with congenital abnormality is $26.6 \%$ and normal is $73 \%$ like In study done by Akhter S et al on Fetal outcome in singleton pregnancies complicated with polyhydramnios from 28 to 36 weeks presented with 10 (20\%) out of total congenital abnormality and 40 (80\%) normal. $^{16}$

In the present study total number of polyhydramnios cases were 60 , cleft lip and cleft palate was noted in 3 and congenital heart disease in 3, anencephaly in 2, hydrocephalus 1 , duodenal atresia 2 , spina bifid 2, and oesophageal atresia 2. Anisa Fawad conducted a study where total number of cases of polyhydramnios was 70 and found congenital abnormality as anencephaly in maximum number of cases, duodenal atersia, oesophageal atresia and gastroschisis two each. ${ }^{10,13}$

Present study subjects presented in 20-27 weeks of gestation were $3.3 \%, 28-36$ weeks $6.6 \%$ and $37-42$ weeks $90 \%$ comparable tostudy done by Akram H, Nasir A, Rana $\mathrm{T}$ on increasing severity of polyhydramnios - a risk factor for congenital malformation conducted in Lady Willingdon hospital, Lahore presented with the result of subjects in 20-27 weeks of gestation were 10 $(16.6 \%)$, in $28-36$ weeks of gestation were $28(46.6 \%)$ and in 37-42 weeks of gestation were $28(46.6 \%)$ and in $37-42$ weeks of gestation were $22(36.6 \%){ }^{15}$

In present study the probable aetiological factor for polyhydramnios was idiopathic in $65.1 \%$, fetal congenital abnormality in $26.6 \%$ and gestational diabetes mellitus in $8.3 \%$. The exact aetiology of polyhydramnios is not 
known but the probable aetiological factors are fetal congenital anamolies (20\%), multiple pregnancy (10\%), placental abnormality, maternal diabetes and idiopathic (50\%). In other studies like Naser Omar Mustafa Malas Princess Haya Hospital Jordan the probable cause were fetal congenital anamolies $3.9 \%$, gestational diabetes mellitus $24.4 \%$ and idiopathic to be in $60.7 \% .^{14}$ Sometime uncontrolled diabetes in first trimester leads to congenital anomaly in the fetus which causes polyhydramnios in mothers, so ultrasound examination at 18-22 weeks is mandatory to exclude major congenital abnormalities and structural defects at this stage. ${ }^{17,18}$

In a study conducted by Phelan et al, an increased incidence of fetal macrosomia, premature births, nonreactive non stress tests, perinatal morbidity, and fetal anomalies was observed. These data suggest that if polyhydramnios is encountered during an ultrasound evaluation, consideration should be given to the possibility of latent or uncontrolled diabetes mellitus or fetal macrosomia or anomaly. Fetal surveillance and genetic evaluation also should be consideration. ${ }^{19}$

\section{CONCLUSION}

Development of excessive amniotic fluid in course of pregnancy signals danger to the foetus. Ultrasonography is the best means for early detection of polyhydramnios. Diagnosis of polyhydramnios is useful means for identification of high risk cases and may often lead to a successful search for congenital anomalies. The above study concludes that the incidence of polyhydramnios $1.25 \%$. The amniotic fluid index provides a reproducible means of evaluating amniotic fluid volume. A careful study must be done for detection of etiological factors in all cases of polyhydramnios, careful screening, prenatal and antenatal counselling will help to improve the foetal outcome as well as to prevent the maternal complication.

\section{ACKNOWLEDGEMENTS}

Authors would like to thanks the institute to allow us to carry out this study and women who participated in this study.

Funding: No funding sources

Conflict of interest: None declared

Ethical approval: The study was approved by the Institutional Ethics Committee

\section{REFERENCES}

1. Queeran JT, Gadow EC. Polyhydramnios: chronic versus acute. Am J ObstetGynecol. 1970;108:349-52.

2. Magann EF, Doherty DA, Chauhan SP, Busch FW, Mecacci F, Morrison JC. How well do the amniotic fluid index and single deepest pocket indices (below the 3rd and 5th and above the 95th and 97th percentile) predict oligohydramnios and hydramnios? Am J Obstet Gynecol. 2004;190:164-9.

3. Cardwell MS. Polyhydramnios. A review Obstet Gynecol Survey. 1987;42:612-7.

4. Hibbard BM. The fetal membranes and amniotic fluid. In: principles of obstetrics, Butter Worth and Co. (Pub); 1988:94-98.

5. Pauer HU, Viereek V, Krauss V, Osmers R, KraussT. The incidence of fetal malformations in pregnancies complicated by oligo and polyhydramnios. Arch Gynecol Obstet. 2003;268:52-6.

6. Thompson O, Brown R, Gunnarson G, Harrington K. Prevalence of polyhydramnios in the third trimester in a population screened by first andsecond trimester ultrasonography. J Perinat Med. 1998;26:371-7.

7. Erdemoglu E, Mungan T. Significance of detecting insulin like growth factor binding protein-1 in cervicovaginal secretions: comparison with nitrazine test and amniotic fluid volume assessment. Acta Obstet Gynecol. 2004;83:622-6.

8. Dashe JS, Mclntire DD, Ramus RM, Santos-Ramos R, Twickler DM. Hydramnios anomaly prevalence and sonographic detection. Obstet Gynecol. 2002;100:1349.

9. Phelan JP, Martin Gl. Polyhydramnios fetal andneonatal complications. Clin Perinatol. 1989;16:987.

10. Lazebnik NN, Lazebnik A. The severity of polyhydramnios, estimated fetal weight and preterm delivery are independent risk factors for presence of congenital malformation. Gynecol Obstet Invest. 1999;48:28-32.

11. Plating-kemp A, Ngu Yen T, Chang E. Idiopathic polyhydramnios and perinatal outcome. Am J Obstet Gynecol. 1999;181:1079-82.

12. Fawad A, Shamshad, Danish N. Frequency, causes and outcome of polyhydramnios. Gomal J Med Sci. 2008;6:2.

13. Tariq S, Cheema S. Polyhydramnios; study of causes and fetal outcome. Professional Med J Dec. 2010;17(4):660-4.

14. Malas NOM, Jayousi TM. Perinatal outcome in idiopathic polyhydramnios. Bahrain Medical Bulletin. 2005;27:1.

15. Akram H, Nasir A, Rana T. Increasing severity of polyhydramnios-A risk factor for congenital malformation. Biomedica. 2006;22:9-11.

16. Akhter S, Mustafa N. Fetal outcome in singleton pregnancies complicated with polyhydramnios from 28 to 36 weeks. Combined Military Hospital. 2011:3.

17. Phelan JP, Park YM, Ahn MO, Rutherford SE. Polyhydramnios and perinatal. 1990;10;347-50.

18. Smith CV, Plambeck RD, Rayburn WF, Albaugh KJ. Relation of mild idiopathic polyhydramnios to perinatal outcome. Obstet Gynecol. 1992;79;387-9.

19. Nordstrom L, Westgren M. Indomethacin treatment for polyhydramnios. Effective but potentially dangerous. Acta Obstet Gynecol Scand. 1992;71;239-41.

Cite this article as: Rajgire AA, Borkar KR, Gadge AM. A clinical study of fetomaternal outcome in pregnancy with polyhydramnios. Int J Reprod Contracept Obstet Gynecol 2017;6:145-8. 